\title{
Decompressive craniectomy versus conservative treatment: limits and possibilities in malignant stroke
}

\author{
Craniectomia descompressiva versus tratamento conservador: \\ limites e possibilidades no AVC maligno \\ Isaac Holanda Mendes MAIA', Thaissa Pinto de MELO², Fabrício Oliveira LIMA', \\ João José de Freitas CARVALHO', Francisco José Arruda MONT'ALVERNE', Edson LOPES JÚNIOR', \\ Marcelo Bezerra DIÓGENES ${ }^{4}$, Thaís Saraiva Leão CUNHA4 , Bárbara Matos Almeida QUEIROZ4, \\ Marina Franciss TAMIETTI4, Fernanda Martins MAIA ${ }^{1}$
}

\begin{abstract}
Background: Malignant infarction of the middle cerebral artery (MCA) occurs in a subgroup of patients with ischemic stroke and early decompressive craniectomy (DC) is one of its treatments. Objective: To investigate the functional outcome of patients with malignant ischemic stroke treated with decompressive craniectomy at a neurological emergency center in Northeastern Brazil. Methods: Prospective cohort study, in which 25 patients were divided into two groups: those undergoing surgical treatment with DC and those who continued to receive standard conservative treatment (CT). Functionality was assessed using the modified Rankin Scale (mRS), at follow-up after six months. Results: A favorable outcome (mRS $\leq 3$ ) was observed in $37.5 \%$ of the DC patients and $29.4 \%$ of CT patients ( $p=0.42$ ). Fewer patients who underwent surgical treatment died (25\%), compared to those treated conservatively (52.8\%); however, with no statistical significance. Nonetheless, the proportion of patients with moderate to severe disability (mRS 4-5) was higher in the surgical group (37.5\%) than in the non-surgical group (17.7\%). Conclusion: In absolute values, superiority in the effectiveness of DC over CT was perceived, showing that the reduction in mortality was at the expense of increased disability.
\end{abstract}

Keywords: stroke; brain edema; decompressive craniectomy.

\section{RESUMO}

Introdução: O infarto maligno da artéria cerebral média (ACM) ocorre em um subgrupo de pacientes com acidente vascular cerebral (AVC) isquêmico e a craniectomia descompressiva (CD) precoce é um de seus tratamentos. Objetivo: Investigar o desfecho funcional de pacientes com acidente vascular cerebral isquêmico maligno submetidos à craniectomia descompressiva em um centro de emergência neurológica do nordeste do Brasil. Métodos: Nesta coorte prospectiva, os pacientes foram divididos em dois grupos: aqueles submetidos a tratamento cirúrgico com craniectomia descompressiva (CD) e aqueles que mantiveram tratamento conservador (TC) padrão. A funcionalidade foi avaliada por meio da Escala de Rankin modificada (ERm) ao final de seis meses de seguimento. Resultados: Evidenciou-se desfecho favorável (ERm $\leq 3)$ em 37,5\% dos pacientes craniectomizados e em 29,4\% dos pacientes não craniectomizados ( $p=0,42$ ). A mortalidade foi menor no grupo de pacientes que se submeteram a tratamento cirúrgico (25\%) do que entre aqueles tratados conservadoramente (52,8\%), porém sem significância estatística. Por outro lado, a proporção de pacientes com incapacidade moderada a grave (ERm 4-5) foi maior no grupo cirúrgico (37,5\%) do que no grupo não cirúrgico (17,7\%). Conclusão: Em valores absolutos, percebeu-se superioridade na eficácia do tratamento cirúrgico sobre o conservador, mostrando que a redução de mortalidade se dá à custa de aumento da incapacidade funcional.

Palavras-chave: acidente vascular cerebral; edema encefálico; craniectomia descompressiva.

\footnotetext{
${ }^{1}$ Hospital Geral de Fortaleza, Serviço de Neurologia, Fortaleza CE, Brazil.

${ }^{2}$ Hospital Geral de Fortaleza, Serviço de Enfermagem, Fortaleza CE, Brazil.

${ }^{3}$ Hospital Geral de Fortaleza, Serviço de Neurocirurgia, Fortaleza CE, Brazil.

${ }^{4}$ Universidade de Fortaleza, Centro de Ciências da Saúde, Fortaleza CE, Brazil.

Isaac Holanda Mendes MAIA (D) https://orcid.org/0000-0001-5482-9736; Thaissa Pinto de MELO (D) https://orcid.org/0000-0003-4905-0714; Fabrício Oliveira LIMA (iD https://orcid.org/0000-0002-0383-4145; João José de Freitas CARVALHO (iD https://orcid.org/0000-0002-1070-5552; Francisco José Arruda MONT'ALVERNE (DD https://orcid.org/0000-0003-0362-257X; Edson LOPES JÚNIOR (iD https://orcid.org/0000-0001-5106-9006; Marcelo Bezerra DIÓGENES (DD https://orcid.org/0000-0002-6204-889X; Thaís Saraiva Leão CUNHA (iD https://orcid.org/0000-0002-6763-3107; Bárbara Matos Almeida QUEIROZ (D) https://orcid.org/0000-0001-8519-4729; Marina Franciss TAMIETTI (D) https://orcid.org/0000-0003-0534-3523; Fernanda Martins MAIA (D) https://orcid.org/0000-0001-6548-7268
}

Correspondence: Isaac Holanda Mendes Maia; Hospital Geral de Fortaleza; Rua Ávila Goulart, 900 - Papicu; 60175-295 Fortaleza CE, Brazil; E-mail: isaacholanda@hotmail.com

Conflict of interest: There is no conflict of interest to declare.

Received on August 1, 2019; Received in its final form on November 27, 2019; Accepted on January 8, 2020. 
Mortality in extensive ischemic stroke (EIS) in the territory of the middle cerebral artery (MCA) can reach up to $80 \%$ according to some controlled studies ${ }^{1,2}$. Transtentorial herniation is the most common cause of death ${ }^{3}$. In view of this scenario, the selection of patients for early prophylactic decompressive craniectomy (DC) surgery is an essential measure in the treatment of acute neurovascular syndrome in emergency neurological services worldwide ${ }^{4}$.

EIS is said to be malignant when there is neurological deterioration secondary to extensive cerebral infarction and consequent encephalic edema, which in turn usually occurs between the second and fifth day after the stroke $e^{5,6,7}$. The patient may present clinical signs of intracranial hypertension, such as headache, nausea, vomiting, anisocoria, epileptic crisis, mental confusion, lowering of consciousness level and coma ${ }^{8,9,10}$.

Two forms of malignant ischemic stroke management are recognized: isolated conservative treatment (CT) and surgical treatment associated to clinical measures, such as osmotherapy with mannitol or hypertonic saline ${ }^{11,12,13,14}$. The first multicenter randomized controlled trials that sought to evaluate the benefit of DC surgery were the HAMLET (Hemicraniectomy After Middle cerebral artery infarction with Life-threatening Edema trial) in 2006, the DECIMAL (DEcompressive Craniectomy In MALignant MCA Infarction) and the DESTINY I (Decompressive Surgery for the Treatment of Malignant Infarction of the Middle Cerebral Artery) in 2007. They established benefits in the survival of patients under 60 years of age undergoing early surgical decompression for malignant stroke, when compared to CT. However, such studies did not assess the quality of life of these survivors. Often, the survival of patients undergoing DC was accompanied by serious sequelae, such as tetraparesis, aphasia, chronic pain and depression. The choice of treatment in the EIS has become a real dilemma for neurologists, neurosurgeons and intensive care specialists, mainly with the advent of new knowledge from so-called Palliative Medicine ${ }^{15,16,17}$. Therefore, this study aimed to evaluate the functional outcome of patients with malignant ischemic stroke treated in a neurological emergency center in the Northeast of Brazil, submitted to DC surgery or not.

\section{METHODS}

This was a prospective cohort study, in which all patients with MCA malignant ischemic stroke treated by the neurological emergency service of the General Hospital of Fortaleza City, Ceará State, Brazil, from November $1^{\text {st }}, 2015$ to December $30^{\text {th }}$, 2016, were evaluated. The inclusion criteria were diagnosis of ischemic stroke with an ictus of 48 hours or less, an extensive ischemic area measured with cranial CT ( $>50 \%$ of MCA territory), neurological deterioration and clinical signs of intracranial hypertension.
The initial sample of 29 patients was divided into two groups: 10 patients who were treated with DC surgery and 19 who continued receiving gold-standard conservative treatment in the stroke unit, with the support of the specialized multidisciplinary team, including neurologists, nurses, physiotherapists, occupational therapists, speech therapists and dentists. Two patients from the craniectomized group and two patients from the non-craniectomized group were lost from the follow-up, thus providing a final sample of 25 individuals.

The patients were monitored by the Neurology and Neurosurgery team during hospitalization and reassessed by telephone, after six months, by the Neurology team. The functional status of both groups was compared to the modified Rankin Scale (mRS). The favorable functional outcome of mild impairment (mRS 0-3) was adopted as the primary outcome. A mRS between 4 and 5 represents moderate to severe disability, which together with an mRS of 6, comprised the total of unfavorable outcomes. The magnitude of the neurological deficit was quantified with the standard National Institutes of Health Stroke Scale (NIHSS), stratified as mild (0-10), moderate (11-18) and severe (>18). The level of consciousness was measured with the Glasgow Coma Scale (GCS) score, as severe ( $\leq 8)$, moderate (between 9 and 12) and mild (between 13 and 15).

Data were analyzed using the IBM SPSS version 23 software. Absolute and relative frequencies were calculated for the qualitative variables and mean and standard deviation for the quantitative variables. The quantitative measures were evaluated for normality using the Shapiro-Wilk test. Student's t-test, the Mann-Whitney test and the chisquared test were used to examine the association between variables. The results were presented in graphs and tables. For all the inferential procedures used, a significance level of $5 \%$ was adopted.

\section{RESULTS}

In the sample analyzed, most patients with EIS in both groups were women, representing $70.6 \%$ of the patients that received the conservative treatment and $50 \%$ of the patients that underwent craniectomy. Ages ranged from 21 to 67 , with the majority corresponding to the age group between 21 and 59 (75.0\% in CD group and $88.2 \%$ in CT group), as presented in Figure 1. Regarding origin, $62.5 \%$ of the surgical patients and $70.5 \%$ of the non-surgical patients lived in Fortaleza City, as presented in Table 1.

The most prevalent risk factors in both populations were systemic hypertension, sedentary lifestyle and smoking. Most patients treated in the referral service were sedentary $(\mathrm{n}=20)$. Smoking ranked as the second risk factor $(\mathrm{n}=16)$, followed by systemic hypertension ( $\mathrm{n}=15)$, as shown in Table 1 . Some patients presented more than one factor. Regarding the 
Craniectomy group $(\mathrm{n}=\mathbf{8})$

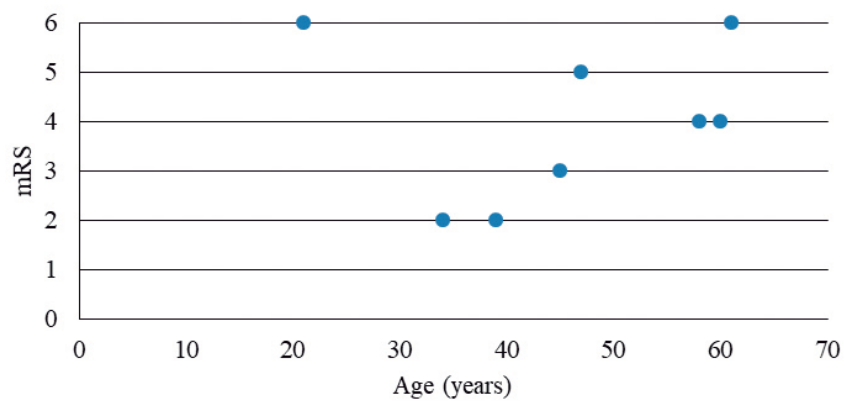

Conservative group $(n=17)$

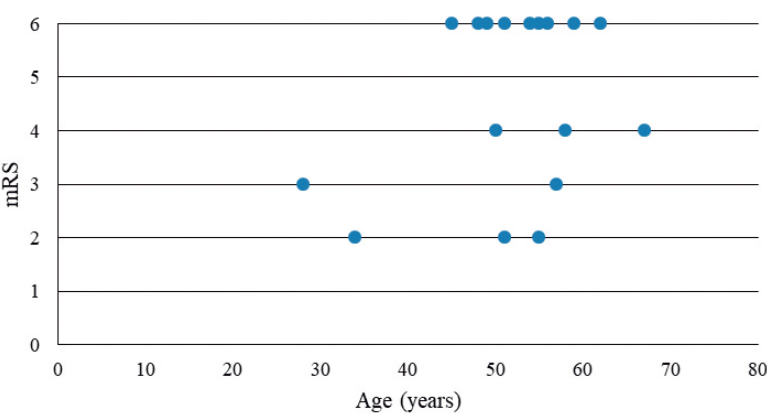

Figure 1. Distribution by age of patients treated conservatively and surgically in a neurological emergency center after malignant ischemic stroke.

Table 1. Sociodemographic and etiological profile of the patients affected by malignant ischemic stroke of a neurological emergency center.

\begin{tabular}{|c|c|c|c|c|}
\hline \multirow{2}{*}{ Variable } & \multicolumn{4}{|c|}{ Group } \\
\hline & \multicolumn{2}{|c|}{ Craniectomy } & \multicolumn{2}{|c|}{ Conservative } \\
\hline Male & 4 & 50.0 & 5 & 29.4 \\
\hline Female & 4 & 50.0 & 12 & 70.6 \\
\hline \multicolumn{5}{|l|}{ Age group } \\
\hline $21-60$ & 6 & 75.0 & 15 & 88.2 \\
\hline$\geq 60$ & 2 & 25.0 & 2 & 11.8 \\
\hline \multicolumn{5}{|l|}{ Origin } \\
\hline Fortaleza City & 5 & 62.5 & 12 & 70.5 \\
\hline Metropolitan region & 2 & 25.0 & 0 & 0 \\
\hline Countryside of the state & 1 & 12.5 & 5 & 29.5 \\
\hline \multicolumn{5}{|l|}{ Associated factor } \\
\hline Systemic hypertension & 5 & 62.5 & 11 & 64.7 \\
\hline Diabetes mellitus & 1 & 12.5 & 4 & 23.5 \\
\hline Dyslipidemia & 1 & 12.5 & 3 & 17.6 \\
\hline Previous stroke & 0 & 0 & 3 & 17.6 \\
\hline Sedentary lifestyle & 7 & 87.5 & 13 & 76.5 \\
\hline Family history of stroke & 3 & 37.5 & 6 & 35.6 \\
\hline Chagas disease & 0 & 0 & 2 & 11.8 \\
\hline Oral contraceptive use & 0 & 0 & 1 & 5.9 \\
\hline Obesity & 1 & 12.5 & 1 & 5.9 \\
\hline Congestive heart failure & 1 & 12.5 & 5 & 29.4 \\
\hline Arrhythmia & 1 & 12.5 & 1 & 5.9 \\
\hline Traumatic brain injury & 1 & 12.5 & 0 & 0 \\
\hline Valvopathies & 0 & 0 & 1 & 5.9 \\
\hline Migraine & 1 & 12.5 & 2 & 11.8 \\
\hline Smoker & 3 & 37.5 & 13 & 76.5 \\
\hline \multicolumn{5}{|l|}{ Previous Rankin } \\
\hline $0-1$ & 8 & 100 & 16 & 94.1 \\
\hline 4 & 0 & 0 & 1 & 5.9 \\
\hline \multicolumn{5}{|l|}{ Mechanism } \\
\hline Cardioembolic & 3 & 37.5 & 5 & 29.5 \\
\hline Cryptogenic & 5 & 62.5 & 11 & 64.7 \\
\hline Large vessels & 0 & 0 & 1 & 5.8 \\
\hline
\end{tabular}


previous functionality, evaluated with the modified Rankin Scale (mRS), Table 2 shows that most patients had no significant disability and that all the patients that had craniectomy were functionally independent regarding activities of daily living. One individual in the surgical group (3.5\%) had a moderately severe disability $(\mathrm{mRS}=4)$ prior to the stroke.

Most patients were able to reach the neurological referral service within the therapeutic window period for intravenous thrombolytic administration (4.5 hours after onset of symptoms), totaling 11 cases (38\%). Nine patients $(31 \%)$ arrived between 4.5-8 hours after the onset of symptoms, and nine $(31 \%)$ patients arrived with an interval of more than 8 hours. Only one patient received thrombolytic therapy with alteplase. According to the etiological investigation of the stroke, 16 cases of the total sample had no defined etiology.
Seven patients had cardioembolic etiology and only one case presented large vessels mechanism (Table 1).

Regarding the clinical manifestations at the time of admission, all the patients presented motor and sensory symptoms. Twenty patients presented speech changes and visual changes. In addition, $64 \%$ of the patients had altered levels of consciousness. Only five patients had headaches, three had a seizure episode, and vomiting was reported in $20 \%$ of the cases (Table 3). At admission, $25 \%$ of the craniectomized patients and $23.5 \%$ of non-craniectomized patients arrived at the hospital with a Glasgow Coma Scale score considered severe $(\mathrm{GCS}<8) ; 62.5 \%$ of the surgical patients and $35.3 \%$ of the non-surgical patients had a moderate score (9-12), and $12.5 \%$ of the craniectomized patients and $41.2 \%$ of the non-craniectomized patients presented a mild GCS

Table 2. Clinical profile of the patients affected by malignant ischemic stroke of a neurological emergency center.

\begin{tabular}{|c|c|c|c|c|}
\hline \multirow{3}{*}{ Variable } & \multicolumn{4}{|c|}{ Group } \\
\hline & \multicolumn{2}{|c|}{ Craniectomy $(n=8)$} & \multicolumn{2}{|c|}{ Conservative $(n=17)$} \\
\hline & $\mathrm{n}$ & $\%$ & $\mathrm{n}$ & $\%$ \\
\hline \multicolumn{5}{|c|}{ Onset of symptoms-admission } \\
\hline$\leq 4.5$ hours & 2 & 25.0 & 6 & 35.3 \\
\hline $4.5-6$ hours & 0 & 0 & 5 & 29.4 \\
\hline$>6$ hours & 6 & 75.0 & 6 & 35.3 \\
\hline \multicolumn{5}{|l|}{ Side affected } \\
\hline Right & 2 & 25.0 & 9 & 52.9 \\
\hline Left & 6 & 75.0 & 8 & 47.0 \\
\hline \multicolumn{5}{|c|}{ Glasgow Coma Scale score-admission } \\
\hline Serious & 2 & 25.0 & 4 & 23.5 \\
\hline Moderate & 5 & 62.5 & 6 & 35.3 \\
\hline Mild & 1 & 12.5 & 7 & 41.2 \\
\hline \multicolumn{5}{|l|}{ NIHSS score-admission } \\
\hline Moderate & 3 & 37.5 & 8 & 47.1 \\
\hline Serious & 5 & 62.5 & 9 & 52.9 \\
\hline \multicolumn{5}{|l|}{ Banford score - admission } \\
\hline LACS & 1 & 12.5 & 0 & 0 \\
\hline PACS & 0 & 0 & 4 & 23.5 \\
\hline TACS & 7 & 87.5 & 13 & 76.5 \\
\hline \multicolumn{5}{|l|}{ Thrombolysis } \\
\hline Yes & 0 & 0 & 0 & 0 \\
\hline No & 8 & 100 & 17 & 100 \\
\hline Presence of anisocoria & 3 & 37.5 & 4 & 23.5 \\
\hline \multicolumn{5}{|l|}{ Final Rankin score } \\
\hline $0-3$ & 3 & 37.5 & 5 & 29.4 \\
\hline $4-6$ & 5 & 62.5 & 12 & 70.6 \\
\hline \multicolumn{5}{|l|}{ Physiotherapy time } \\
\hline$>=3$ months & 4 & 66.7 & 6 & 35.3 \\
\hline$<3$ months & 2 & 33.3 & 11 & 64.7 \\
\hline
\end{tabular}


(13-15). Regarding the magnitude of the neurological damage calculated by the NIHSS score, no individual was classified as mild NIHSS (0-10), 11 patients had moderate NIHSS (11-18), and the majority of patients $(\mathrm{n}=14)$ had NIHSS considered severe $>18$ ). In relation to the cerebral hemisphere involved, the majority of craniectomized patients had their left side affected $(n=6)$, whereas most of conservative patients had their right hemisphere more affected $(n=9)$ (Table 1 ).

Regarding the functionality of the patients with malignant stroke at the 6-month follow-up, Figure 2 shows the percentage of all functional outcomes according to the mRS, whereas Table 4 divides the two groups into favorable outcome (mRS 0-3), unfavorable outcome (mRS 4-5) and death (mRS=6). Most patients who received conservative treatment evolved to death (52.8\%). In addition, 37.5\% (3/8) of the craniectomized patients and $29.4 \%(5 / 17)$ of the non-craniectomized patients achieved a favorable outcome of mild disability (mRS 0-3), whereas $37.5 \%$ (3/8) of the patients in the craniectomized group and $17.6 \%$ (3/17) of the non-craniectomized group had moderate to severe disability (mRS 4-5) after six months. Mortality (mRS=6) was $2.1 \%(2 / 8)$ among surgical patients and $52.9 \%(9 / 17)$ among those treated

Table 3. Clinical manifestation of patients with malignant ischemic stroke treated at a neurological emergency center.

\begin{tabular}{lcc}
\hline Clinical manifestation & $\mathrm{n}$ & $\%$ \\
\hline Motor & 25 & 100 \\
Sensitive & 25 & 100 \\
Aphasia & 20 & 80 \\
Visual & 20 & 80 \\
Consciousness & 16 & 64 \\
Headache & 5 & 20 \\
Vomiting & 5 & 20 \\
Convulsive crisis & 3 & 12 \\
Hemineglect & 4 & 16 \\
\hline
\end{tabular}

conservatively. Of those who died, $81.8 \%$ presented a cause of death related to brain herniation. One patient died of sudden cardiac arrest 10 months after discharge. The mean time between the stroke and death was 6.8 days.

\section{DISCUSSION}

The average age of patients in our sample was $50.0 \pm 10.9$, whereas in the study by Vital et al. ${ }^{18}$ it was 63 (32-83). Patients were allocated to the groups within 48 hours of the stroke, with this time being 30 hours for the DECIMAL study, 96 hours for the HAMLET, 36 hours for the DESTINY I and 48 hours for the DESTINY II. The mean time between the onset of symptoms and admission to the emergency room was 7 hours (range 2-25). In the studies by Bongiorni et al. ${ }^{19}$ at the Hospital de Clínicas de Porto Alegre, Brazil, the average was $13.2 \pm 1.4$ hours. The mean NIHSS admission score in the DECIMAL study was 22.5 for the surgery group and 23.4 for the non-surgery group, whereas in the present sample it was 20.7 and 19.9, respectively, showing that the patients of the present study were in a less serious condition upon arrival at the neurological referral service.

In the study by Mattos et al. ${ }^{20}$, patients with GCS $<8$ in the preoperative examination showed a tendency for poor outcomes, which represented a quarter of the craniectomized patients in the present study. The mean ictus-craniectomy interval for the patients of the present study was 39.7

Table 4. Stratification of the modified Rankin Scale at the end of the 6-month follow-up in patients with ischemic stroke treated in a neurological emergency center.

\begin{tabular}{ccccc} 
Variables & & Craniectomy & Conservative & $p$-value \\
\hline \multirow{2}{*}{ RANKIN } & $0-3$ & $3(37.5)$ & $5(29.4)$ & \\
& $4-5$ & $3(37.5)$ & $3(17.7)$ & 0.420 \\
& 6 & $2(25.0)$ & $9(52.9)$ & \\
\hline
\end{tabular}

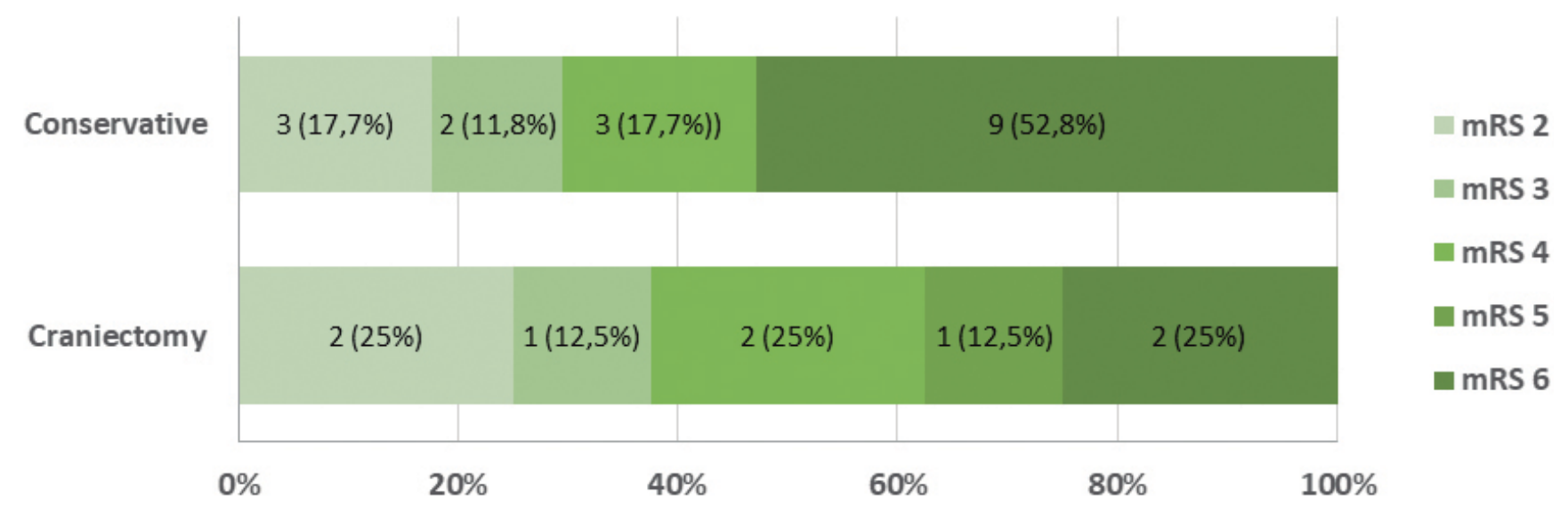

Figure 2. Functional capacity measured with the mRS after 6 months in two therapeutic groups (Decompressive Craniectomy vs. Conservative) of patients with malignant ischemic stroke. 
hours, whereas in the DECIMAL it was 20.5 hours (interval between 7 and 43 hours). In studies on MCA hemispheric infarction, Fiorot Junior et al. ${ }^{21}$ published that the mean age of patients was $59.1 \pm 18.0$, whereas in our sample it was $50.0 \pm 10.9$, with $46.6 \pm 13.2$ in the DC group and $51.8 \pm 9.3$ in the CT group. When risk factors were analyzed, $31.0 \%$ of the craniectomized patients and $22 \%$ of the non-craniectomized DECIMAL patients were hypertensive, whereas in the present study these figures were $62 \%$ and $64.7 \%$, respectively, thus showing an unsatisfactory control of modifiable risk factors, such as hypertension.

The cardioembolic mechanism was the most prevalent in the present sample, found in $37.5 \%$ in the surgical group and $29.5 \%$ in the non-surgical group. The mean time between symptom onset and therapeutic decision among patients with hemispheric infarction in the study by Fiorot Junior et al. ${ }^{21}$ was 33 hours for craniectomized patients and 37 hours for non-craniectomized patients, whereas, in our study, 26.5 and 31 hours, respectively. In the DESTINY I study, these values were $24.4 \pm 6.9$ and $23.8 \pm 7.8$ hours, showing that the time for making decisions about the type of treatment in our hospital is similar to international data.

In the analysis of functionality between the two therapeutic groups, the present study showed that the favorable outcome (mRS 0-3) after 6 months was better among the patients who underwent DC surgery when compared to those on CT, numerically corresponding to $37.5 \%(3 / 8)$ of the craniectomized patients compared to $29.4 \%$ (5/17) of the non-craniectomized patients. The proportion of patients with moderate to severe disability (mRS 4-5) was higher in the surgical group $(37.5 \%)$ than in the non-surgical group (17.7\%), proving that survival is accompanied by a reduction in functionality. Furthermore, the number of deaths (mRS=6) among the patients who underwent DC ( $25 \%$ mortality) was lower when compared to those on CT (52.9\% mortality). Studies of DC in patients with traumatic brain injury showed that the procedure, even after clinical signs of brain herniation, can still lead to better functional outcomes compared to conservative treatment ${ }^{22}$. Although this has not shown such benefit in stroke studies, in our sample, even with a rate of $37.5 \%$ of patients in the $\mathrm{CD}$ group with anisocoria, $\mathrm{CD}$ brought a favorable outcome (mRS) for $37.5 \%$ of them. In the international literature, the DESTINY I study, with the inclusion of 32 patients, revealed a statistically significant reduction in mortality: 15 (88\%) of the 17 patients randomized to hemicraniectomy versus 7 (47\%) of the 15 patients randomized to conservative therapy survived after 30 days ( $\mathrm{p} \leq 0.02$ ).

In the study by Kim et al. ${ }^{23}$ on the attitude of patients as to their disability after MCA hemispheric stroke, $55 \%$ of patients considered an mRS score of 3 to be the worst disability acceptable.

In sum, it is concluded that although DC surgery is a procedure that reduces mortality, the increased survival is accompanied by serious functional disability. Accordingly, it is important for the medical team to inform family members about the risks, susceptibilities and likely postoperative functional outcome for patients, considering that many of them will require lifelong special and individualized care.

\section{References}

1. Mohan Rajwani K, Crocker M, Moynihan B. Decompressive craniectomy for the treatment of malignant middle cerebral artery infarction. Br J Neurosurg. 2017 Aug;31(4):401-9. https://doi.org/10.1 080/02688697.2017.1329518

2. Das S, Mitchell P, Ross N, Whitfield PC. Decompressive hemicraniectomy in the treatment of malignant middle cerebral artery infarction: a meta-analysis. World Neurosurg. 2019 Mar;123:816. https://doi.org/10.1016/j.wneu.2018.11.176

3. Algethamy HM, Samman A, Baeesa SS, Almekhlafi MA, Al Said YA, Hassan A. Decompressive hemicraniectomy for malignant middle cerebral artery infarction-Experience from the Western Province of Saudi Arabia. Neurosciences (Riyadh). 2017 Jul;22(3):192-7. https:// doi.org/10.17712/nsj.2017.3.20170051

4. Rahme R, Curry R, Kleindorfer D, Khoury JC, Ringer AJ, Kissela BM, et al. How often are ischemic stroke patients eligible for decompressive hemicraniectomy? Stroke. 2012 Feb;43(2):550-2. https://doi. org/10.1161/STROKEAHA.111.635185

5. Treadwell SD, Thanvi B. Malignant middle cerebral artery (MCA) infarction: pathophysiology, diagnosis and management. Postgrad Med J. 2010 Apr;86(1014):235-42. https://doi.org/10.1136/ pgmj.2009.094292

6. Wartenberg KE. Malignant middle cerebral artery infarction. Curr Opin Crit Care. 2012 Apr;18(2):152-63. https://doi.org/10.1097/ MCC.0b013e32835075c5
7. Staykov D, Gupta R. Hemicraniectomy in malignant middle cerebral arter infarction. Stroke. 2011; 42:513-6. https://doi.org/10.1161/ STROKEAHA.110.605642

8. Huttner HB, Schwab S. Malignant middle cerebral artery infarction: clinical characteristics, treatment strategies, and future perspectives. Lancet Neurol. 2009 Oct;8(10):949-58. https://doi. org/10.1016/S1474-4422(09)70224-8

9. Wijdicks EFM, Sheth KN, Carter BS, Greer DM, Kasner SE, Kimberly WT, et al. Recommendations for the management of cerebral and cerebellar infarction with swelling: a statement for healthcare professionals from the American Heart Association/American Stroke Association. Stroke. 2014 Apr;45(4):1222-38. https://doi. org/10.1161/01.str.0000441965.15164.d6

10. Torbey MT, Bosel J, Rhoney DH, Rincon F, Staykov D, Amar $A P$, et al. Evidence-based guidelines for the management of large hemispheric infarction a statement for health care professionals from the Neurocritical Care Society and the German Society for Neuro-Intensive Care and Emergency Medicine. Neurocrit Care. 2015 Feb;22(1):146-64. https://doi. org/10.1007/s12028-014-0085-6

11. Hauer E-M, Stark D, Staykov D, Steigleder T, Schwab S, Bardutzky J. Early continuous hypertonic saline infusion in patients with severe cerebrovascular disease. Crit Care Med. 2011 Jul;39(7):1766-72. https://doi.org/10.1097/CCM.0b013e318218a390 
12. Akins PT, Axelrod YV, Arshad ST, Guppy KH. Initial conservative management of severe hemispheric stroke reduces decompressive craniectomy rates. Neurocrit Care. 2016 Aug;25(1):3-9. https://doi. org/10.1007/s12028-016-0270-x

13. Simard JM, Sahuquillo J, Sheth KN, Kahle KT, Walcott BP. Managing malignant cerebral infarction. Curr Treat Options Neurol. 2011 Apr;13(2):217-29. https://doi.org/10.1007/s11940-010-0110-9

14. Zweckberger K, Juettler E, Bösel J, Unterberg WA. Surgical aspects of de compression craniectomy in malignant stroke: Review. Cerebrovasc Dis. 2014;38(5):313-23. https://doi.org/10.1159/000365864

15. Hofmeijer J, Amelink GJ, Algra A, van Gijn J, MaCleod RM, Kappelle LJ, et al. Hemicraniectomy After Middle cerebral artery infarction with Lifethreatening Edema Trial (HAMLET). Protocol for a randomised controlled trial of decompressive surgery in space-occupying hemispheric infarction. Trials, 2006;7:29. https://doi.org/10.1186/1745-6215-7-29

16. Vahedi K, Vicaut E, Mateo J, Kurtz A, Orabi M, Guichard JP, et al. Sequential-design, multicenter, randomized, controlled trial of early decompressive craniectomy in malignant middle cerebral artery infarction (DECIMAL trial). Stroke. 2007;38(9):2506-17. https://doi. org/10.1161/STROKEAHA.107.485235

17. Juttler E, Schwab S, Schmiedek P, Unterberg A, Hennerici M, Woitzik $J$, et al. Decompressive Surgery for the Treatment of Malignant Infarction of the Middle Cerebral Artery (DESTINY I): a randomized, controlled trial. Stroke. 2007 Sep;38(9):2518-25. https://doi. org/10.1161/STROKEAHA.107.485649
18. Vital RB, Hamamoto Filho PT, Luvizutto GJ, Ducati LG, Braga GP, Nunes HRdC, et al. Decompressive hemicraniectomy in a South American Population - morbidity and outcomes analysis. PLoS ONE. 2016 Jan;11(1): e0146747. https://doi.org/10.1371/journal. pone.0146747

19. Bongiorni GT, Hockmuller MCJ, Klein C, Antunes ACM. Decompressive craniotomy for the treatment of malignant infarction of the middle cerebral artery: mortality and outcomes Arq Neuropsiquiatr. 2017 Jul;75(7):424-8. https://doi.org/10.1590/0004-282X20170053

20. Mattos JP, Joaquim AF, Almeida JP, Albuquerque LA, Silva EG, Marenco HA, et al. Decompressive craniectomy in massive cerebral infarction. Arq Neuropsiquiatr. 2010;68(3):339-45. https://doi. org/10.1590/s0004-282×2010000300002

21. Fiorot Junior JA, Silva GS, Cavalheiro S, Massaro AR. Use of decompressive craniectomy in the treatment of hemispheric infarction. Arq Neuropsiquiatr. 2008;66(2A):204-8. https://doi. org/10.1590/s0004-282x2008000200012

22. Shah A, Almenawer S and Hawryluk G. Timing of decompressive craniectomy for ischemic stroke and traumatic brain injury: a review. Front Neurol. 2019;10:11.https://doi.org/10.3389/fneur.2019.00011

23. Kim B-J, Hong YR, Han Y, Hwang Y-H, Ohk B, Park J. AgeDependent Attitudes of Ischemic Patients towards Disability after Decompressive Hemicraniectomy for Malignant Middle Cerebral Artery Infarction, World Neurosurgery (2018). doi: 10.1016/j. wneu.2018.02.050. 